\title{
International Law, Sovereignty and the Responsibility to Protect: An Overview
}

\author{
Thomas Prehi Botchway ${ }^{1}$ \\ ${ }^{1}$ Law School, Chongqing University, Chongqing, China \\ Correspondence: Thomas Prehi Botchway, Law School, Chongqing University, Shapingba, Chongqing, China. \\ E-mail: abeikuprehi@yahoo.com; prehionline@gmail.com
}

Received: September 1, 2018

doi:10.5539/jpl.v11n4p40

\author{
Accepted: October 3, $2018 \quad$ Online Published: November 30, 2018 \\ URL: https://doi.org/10.5539/jpl.v11n4p40
}

\begin{abstract}
This paper is an attempt at analysing the intricacies between international law, the concept of Responsibility to Protect and its implications for the sovereignty of modern states. The paper examines how the concept of responsibility to protect (as stipulated by the International Commission on Intervention and State Sovereignty (ICISS)) impacts on the sovereignty of states. It adopts the essay style of writing and reviews a number of documents on the subject of international law, sovereignty and the responsibility to protect.

The paper consequently argues that though the ICISS claims that its "purpose is not to license aggression with fine words, or to provide strong states with new rationales for doubtful strategic designs" (ICISS, 2001, p. 35), the Commission's very attempt to exempt the permanent five and other so-called major powers from intervention does just that whether intentionally or unintentionally. It consequently recommends that much effort should be made to address the inequalities within the international system through the formulation of appropriate policies and international regulations that address the sovereign equality of states in the international system, especially on the question of intervention.
\end{abstract}

Keywords: sovereignty, responsibility to protect, international law, sovereign-equality, intervention

\section{Introduction: The International Law and Politics 'Symbiosis'}

Law has over the years been perceived as a traditionally "contingent institutional expression" of politics - which is primarily the "intersection of issues of identity, purpose, ethics, and strategy." (Reus-Smit, 2004) For instance, the philosophy of John Austin postulates that the law "is essentially the effective command of a superior." Thus, it is argued that what the law entails is "not at all a vague and general impression that something ought to be done, but a definite, precise order necessitating certain 'acts or forbearances."” (Merriam Jr., 2001, pp. 70-71) This makes much sense, especially when one perceives politics as a means to the distribution of power. (Dahl, 1957) It then also implies that in any given society or community of persons, the sovereign is the ultimate "source of law" and is therefore "above the binding force of its own decrees." The assumption is that the ultimate source of power cannot be bound by the very laws that s/he pronounces "since there is no power by whom such obligations can be interpreted or enforced" and that "the law giver cannot be legally bound by his own law, however great the moral obligation incurred." (Merriam Jr., 2001, p. 74)

This understanding of the law and the sovereign becomes difficult to sustain if we are to perceive sovereignty as largely the independence of each State in the midst of the community of States and international law as the explicit command of each state to the extent that no other state or group of states can influence or cause it to act against its own will or dictates. It has however been argued elsewhere that the sovereignty of a state implies its independence and that "this independence is indicated by the possession of certain rights which afford a criterion of the existence or nonexistence of sovereign power." Sovereignty, according to this argument consequently becomes "a sum of powers" and that the seemingly decline or "loss of a part" of such powers "does not destroy its existence" since there is "room for the recognition of a semi-sovereign State." (Merriam Jr., 2001, p. 112)

Reus-Smit (2004) by expounding on the position of realist political thinkers such as Hans J. Morgenthau, Edward Hallet Carr, and Alfred Zimmern have posited that "law is fundamentally political and in relations between states the content of international law is determined by dominant states and will not be upheld when it conflicts with their perceived political interests". The argument is that international law, as perceived by realists 
is usually used by powerful and dominant states for their own interest as against the interest of less influential states to the extent that it becomes difficult in decoupling international law from politics. It is consequently asserted that international law is "not enforceable independently of the will of powerful states, and cannot be regarded, in any compelling sense, as binding." (Reus-Smit, 2004, p. 16) One also has to keep in mind that politics, according to Reus-Smit, is:

A variegated, multi-dimensional form of human deliberation and action... that encompasses not just instrumental reason and strategic action, but also forms of reason and action that ordain certain actors with legitimacy, define certain preferences as socially acceptable, and license certain strategies over others. (Reus-Smit, 2004, p. 5)

Consequently, understanding politics in terms of what Reus-Smit has outlined above gives an indication that an incidence like the United States' persistence push for a United Nations Security Council (UNSC) to use military force to disarm and subsequently depose Saddam Hussein's regime in Iraq during the first term of Bush's administration in the early 2000s, its failure to secure the support of the UNSC, massive demonstrations across the world against the US' unilateral decision on Iraq and matters arising all depicts the complexity of the "interplay between politics and law in contemporary international relations". Thus, though "the entire process was deeply political", it is said that "law was implicated at every turn." (Reus-Smit, 2004, p. xiii)

Moreover, attempts by realists and other schools of thought to delineate international law from politics has usually led to situations where international law becomes "caught up in its own methodologies and indulgences" and subsequently been "divorced from the decisions it aspires to influence." (Kritsiotis, 2004, p. 45) For instance, in reference to Japan's venture to use force to takeover the Chinese province of Manchuria in September 1931 and its subsequence events - events that attempted to ignore the attack as an act of war - as indicated by responses from both countries, Kritsiotis has argued that "attitudes toward this narrow endorsement of 'war' in practice suggest that international law... is no more than "the output of a political process"" and that "the law is somehow devalued - its ambitions abruptly affected - by the machinations of the political process because, through the relentless techniques of interpretation, all forms of behaviour can be defended or justified in legal terms." (Kritsiotis, 2004, pp. 53,54) Consequently, most laws (if not all) at both the municipal and international levels of interaction are nothing but edifices of power that have been purposely masked to deceive the unsuspected masses and to dissuade their fears and complaints against the injustices and inequities as well as the parochial interests perpetrated by the supposedly duty bearers in society.

With regards to the ECOWAS' intervention in Liberia (1990), as well as "Operation Provide Comfort" in northern Iraq (1991), and NATO's controversial military intervention over Kosovo (1999), Kritsiotis has indicated that each case at a first glance "would appear to bode ill for the relevance of international law and its impact on the processes of political decision-making within the intervening states." Thus, these cases give a clear indication of the "absence of a conventional basis and authorisation from the Security Council in accordance with its enforcement powers" as provided in Chapter VII of the UN Charter hence amounting to breaches of the UN Charter's prohibition on the use of force. (Kritsiotis, 2004, p. 68)

\section{Understanding Sovereignty and the Variations of the Concept}

If there is one concept or terminology that has over the ages posed a lot of challenges (in terms of its application, definition, defence, understanding, and usefulness) among scholars and practitioners, as well as policy makers, jurists and lawyers alike, that concept would be Sovereignty - a term that can be simply summarized as "the supreme political authority" which "forms the basis for the modern international system" and consequently endows states and governments with legitimacy. Thus, at its barest minimal, sovereignty can be seen as the "control over people and geographic space" which is usually "invested" in a set of institutions and persons that are authorised to manage the affairs of the state - government. (Lansford, 2011, pp. 1580-1581)

In recent times, however, the growth of nonstate and international actors has eroded the traditional power of the nation-state and consequently redefined some aspects of sovereignty (Lansford, 2011). Thus sovereignty may no longer be perceived as just the effective control of a territory and people by an authorised person or group of persons. Sovereignty within the modern state ought to be exercised over a compact area and governments are to be granted a degree of legitimacy and authority unmatched in erstwhile political systems (Lansford, 2011). According to Francis Lieber (1838-39) sovereignty refers to "the right, obligation and power which human society or the State has to do all that is necessary for the existence of man in society", cited in (Merriam Jr., 2001, p. 90).

Though scholars have diverse views on the origins of the sovereign, some assert that, at least in the field of political philosophy and their related field of study, the concept was primarily given much impetus in the works 
of St. Thomas Aquinas in the $13^{\text {th }}$ century. According to Aquinas' conception, there is but one sovereign - God and that "the sovereignty exercised by human rulers came from the divine" which implies that all rulers who claim sovereign ought to "exercise their power in accordance with Christianity". Failure to adhere to Christian principles as a sovereign thus confers the right on the "citizens or other states" to effect the removal of the sovereign (Lansford, 2011, p. 1581).

Aquinas' divine origins of the sovereign have however over the years been challenged by several works (either directly or indirectly). For instance, key proponents of sovereignty such as Thomas Hobbes, John Locke, and JJ Rousseau have all settled for a kind of social contract in which the sovereign becomes the creation of one form of a contract or the other with the people or their will and needs. For example, though Hobbes argues for the absolute nature of the sovereign, he nevertheless contends that the power of the sovereign does not emanate from "the divine but from a social contract between the people and the rulers, in which people surrender some portion of their natural rights in exchange for the government maintaining social order and providing for the common defense of its citizenry." (Lansford, 2011, p. 1581; Hobbes, 1651) Similarly, Jean-Jacques Rousseau has stated that sovereignty is based in the general will or the common good of a population and that there is no distinction between the source of sovereignty and its exercise. Thus, the general will of the citizenry forms the foundation for national sovereignty and the means through which state authority is expressed (Lansford, 2011).

The point is that whereas most scholars are of the view that "the meaning of the concept of sovereignty is open to change across time and space", there are still several groups of persons who still "disagree about the causes and consequences of this conceptual change." Consequently, though most researchers perceive these "changes to be indicative of a corresponding transformation of global institutions", there are still those who consider such changes "as evidence of the remarkable endurance of the Westphalian order." (Bartelson, 2006, p. 463) As a result, sovereignty - the "once relatively uncontested" darling concept of international relations experts and lawyers, as well as political philosophers, has of late "become a major bone of contention" among scholars and practitioners alike. Eventually, in place of what was initially seen as a concept with "timeless or universal meaning", sovereignty is now seen as a concept with "changing meanings... across a variety of historical and political contexts." (Bartelson, 2006, pp. 463-464)

Consequently, the views and opinions of what the sovereign 'is' is as varied as the number of proponents there is. For instance, though prominent scholars including Jean Bodin and Hobbes have argued that sovereignty is absolute, and confers upon a government unconditional powers, there are several others who perceive sovereignty in a limited conception and even divisible (Lansford, 2011; Merriam Jr., 2001; Bodin, 1576).

Though Bodin's conception of sovereignty is usually "credited with giving the sovereignty concept coherence, content, and currency", and though his contribution perceived (rightly or wrongly) to be "committed to the concentration of power in the monarchy" thereby setting the fundamentals of "sovereign absolutism", there is also ample evidence to show that he was "by no means committed to sovereign absolutism." The argument has often been that in order to understand Bodin's conception of the sovereign, it is imperative that his views are properly examined in the "context of the political turmoil of his time." (Nagan \& Haddad, 2012, p. 439)

Nagan and Haddad (2012) have consequently asserted that although "the sovereign is bound by natural and divine law", "Bodin's sovereign is not subject to civil or positive law". According to them, Bodin's conception of the absolute sovereign implies "the concepts of "supreme" or "absolute" are unequivocally limited by natural law, divine law and, to some extent, international law" which means that "Bodin's use of the term absolute is meant to be qualified, and suggests restraints on sovereignty within the domain of natural and international law." (Nagan \& Haddad, 2012, p. 441) A close analysis of his thoughts thus gives an indication that Bodin is not "devoted to unqualified absolutism." Instead, his overreaching concern is with "the practical problem of public order and stability in a time of conflict and social dislocation." It thus becomes more appropriate if the reading of Bodin is seen as "stressing the control element of the idea of sovereignty." (Nagan \& Haddad, 2012, p. 442)

Expounding on Hobbes' conception of the sovereign, Nagan and Haddad (2012) have indicated that "it is essential for sovereignty to have certain rights that cannot be tested" and that such "rights confer powers that must be reliably and effectively used in governance" (p. 442). The Hobbesian conception of sovereignty postulates that the primary obligation of "the sovereign is the obligation to protect the citizen." In consequence, the failure of the sovereign to deliver on this primary obligation implies that his authority over the citizen "no longer holds". (Nagan \& Haddad, 2012, p. 444; Hobbes, 1651) Hobbes' conception of sovereignty posits that "sovereignty and its subjects are created simultaneously" and as such, "sovereignty is not delegated or alienated by the people" since "they were not a people until the sovereignty was created". The point is that "the people never possessed the supreme power, and consequently had no right to dispose of it." (Merriam Jr., 2001, p. 13) 
With regards to Rousseau's general will and the sovereign, it has been argued that " $[t]$ he sovereign has unlimited control over all that affects the general welfare, and the indisputable right to judge as to what falls under this category." Moreover, there is the idea that "[n]o rights are reserved to the individual" and that "no guaranty of rights from sovereign to subject is conclusive." (Merriam Jr., 2001, p. 18) Consequently, the sovereign as envisaged by Rousseau "stands out as absolute, infallible, indivisible" and "inalienable" and consequently "finds its source in an original contract and abides permanently in the body politic, the creature of the compact." (Merriam Jr., 2001, p. 18) Thus, whereas Hobbes determined to create an absolute monarch as the sovereign, Rousseau did the inverse by postulating an absolute sovereign that resides in the people (the government).

Accordingly, beginning from the later parts of the $18^{\text {th }}$ century, several constitutions were promulgated with the sovereignty of the people/nation been the underpinning foundation. The sovereignty of the people was so entrenched to the extent that any individual who was seen as usurping it could "be at once put to death by freemen". Moreover, insurrection was justifiable once "the government violates the rights of the people". The scenario however changed in later years as the State and sovereignty were perceived as the combination of the individuals' natural rights that have been aggregated to structure the "political right of the ruler". Subsequently, in the various versions of the conception of sovereignty, notwithstanding the diversities in the creation and nature of the social contract, the tendency has always been "to rest the supreme power upon a basis of popular consent." (Merriam Jr., 2001, p. 19)

On the one hand, in describing sovereignty and its origins with political philosophy, Aravamudan (2006) has indicated that "...the first step in an analysis of what became a full-fledged literary genre is to acknowledge that modern political philosophy always positioned itself doubly as an explanation of history and also as a flight from it". According to him, this presumably "double stance in political philosophy" has consequently characterized it as both a "descriptive" and a "prospective" concept, thus making sovereignty an "anachronistic" concept. This he argues is occasioned by the multiplicity of "methods of self-exposure and self-critique". He however opines that describing sovereignty on the one hand as anachronistic while on the other hand perceiving discourses on "self determination" as "catachronistic" implies that something is "both truistic and abstruse at once" (Aravamudan, 2006, p. 433). Aravamudan (2006) has further asserted that the ideas of most prominent scholars of sovereignty such as Jean Bodin, Thomas Hobbes, John Locke, among others (as identified above) are "not just superficial mistakes or rhetorical tropes, but the full deployment of anachronistic thought" (Aravamudan, 2006, p. 434).

On the other hand, in explaining the views of those who call for the abandonment of sovereignty as the nucleus for international relations and law, Cohen (2004) has posited that:

Once a useful fiction for imagining international relations, the concept of the sovereign territorial state conceals more than it reveals today. For the networked global political system has allegedly moved beyond mere interdependence to a situation of deep interrelationship and interconnectedness. In short, the background conditions of the international system allegedly no longer involve a baseline of separation, autonomy, and defined territorial or jurisdictional boundaries, but rather entails connection, interaction, and interpenetrating networks and institutions. (Cohen, 2004, p. 7)

During the early and middle ages in Europe, as a consequence of the role and influence of the Catholic Church, which acted as a supranational body with political manifestations in the form of autonomous bishoprics or other church-states, sovereignty was more diffused and limited in scope. This notwithstanding, the church executed an important role in legitimizing the sovereignty of rulers through its involvement in coronations and other practices of formal recognition of feudal rulers. Secular rulers were in response, expected to support the church financially, politically, and militarily (Lansford, 2011).

Notwithstanding that sovereignty at a point in history became so popular among European states, the upsurge in autocratic and totalitarian regimes in Europe in later years (particularly in the twentieth century) led to the rise of antisovereignty movements which sought to discard the "domestic authority of states." This group of scholars and activists consequently favoured internationalization of rights as against the sovereignty of states with its totalitarian tendencies. These included philosophers and scholars as Georges Bataille, Michel Foucault, Jacques Derrida, Bertrand de Jouvenel, Jacques Maritain, etc. (Lansford, 2011).

In spite of the loud cries of the antisovereignty proponents and their followers, there has always been the idea that sovereignty basically forms the nucleus around which every proper functioning of the state revolves and as such, no state can function properly without sovereignty. The argument is that, politics and law which forms the basis for an organised society are intertwined in the sovereign. Hence, sovereignty has been described as "the very relational interface between law and politics, that which both separates these domains and binds them 
together." It is further asserted that "sovereignty represents the autonomy of the political" and also "provides the foundation of public law." Consequently, any assertion that the modern day society has "reached the end of sovereignty" is said to be "rooted in a misunderstanding of the concept of sovereignty and its meaning" and that "sovereignty remains a potent force in the contemporary world." (Bartelson, 2006, p. 469)

\subsection{Limiting the Powers of the Sovereign}

According to Hugo Grotius, natural law, conventions, treaties, and traditions are among the key elements that constraints state sovereignty in external matters (Lansford, 2011). In addition, over the years, the actions and inactions of states are expected to be guided and constrained by certain universally recognised "norms and values". These consequently serve as avenues for 'limiting' the activities of a state across its boundaries and even within the confines of its territories (Lansford, 2011, p. 1582).

Moreover, in the modern world, the $\mathrm{UN}$ and a number of regional organizations have tried to introduce policies through which states surrender some degree of their sovereignty in exchange for access to greater public goods such as peace, security, and economic prosperity (Lansford, 2011; Bartelson, 2006).

Furthermore, the Universal Declaration of Human Rights, the Genocide Convention, the European Convention on Human Rights (1950), etc. impose series of strict protocols on states to protect the rights of citizens. These and other instruments have over the years been used to justify international humanitarian missions, including the use of military force, in order to prevent genocide or protect populations during the Balkan Wars of the 1990s, and recently in Iraq, Syria, Afghanistan, and Libya. Thus, in recent times, the traditional notions of state sovereignty are usually judged, especially by the Western countries, as less important than the international community's responsibility to protect human rights. Moreover, the creation in 2002 of the International Criminal Court with supranational jurisdiction is another manifestation of this trend (Lansford, 2011, p. 1583).

Though several scholars and institutions have in recent times argued that the sovereignty of the modern state is threatened by the continuous development of modern international institutions, especially economic institutions, there are still several others who postulate these institutions rather reinforce the sovereignty of states. A key proponent of the latter is Kal Raustiala who argues that though "changes in the international system or in domestic politics have already compromised sovereignty and thus international institutions", international institutions, "while rendering the erosion of sovereignty more legible, actually serve as a means" for states to "reassert or reclaim" their "sovereignty" (Raustiala, 2003, p. 841).

Raustiala (2003) has consequently argued that a better understanding of the idea that international economic institutions actually enhance their sovereign claims is crucial for two main reasons. Firstly, having such an understanding, according to him, is a tool that comes in handy for challenging the "prevailing wisdom and thus offer an alternative guide for policy." Secondly, it helps in broadening people's "conceptions of sovereignty" thereby reducing the "unduly narrow" and "increasingly anachronistic" views of the sovereign (p. 841). He has consequently asserted that "the language of sovereignty often serves to obscure the real nature of international institutions and typically sheds more heat than light." (Raustiala, 2003, p. 875)

Sovereignty in recent times has arguably become "deeply embedded" in the international system since it is seen as an effective avenue for providing appropriate means for "upholding certain values that are considered to be of fundamental importance" across the globe. (Potter, 2004, p. 8) The international community has subsequently become the most influential agency in determining "which political entities qualify as sovereign states" since it stipulates what the "requirements of sovereignty" are (Potter, 2004, p. 9; Family Watch International (FWI), 2013) Consequently, there is little (or no) disagreement about the fact that the existence of a sovereign power in a hierarchically arranged and clearly determined order is an essential element for the maintenance of serenity and orderliness in society.

The Treaty of Westphalia which was signed at the end of the thirty years war in Europe in 1648 "juridicalized the idea of an international society based on sovereign nation States" and this conception seems to be standing the test of time. (Nagan \& Haddad, 2012, p. 432) This notwithstanding, a recognition that the sovereignty of the modern state, is gradually "being redefined - not least by the forces of globalisation and international co-operation" is an important first step in dealing with the several misconceptions and misapplication of the term. Moreover, in recent times states are generally regarded as "instruments at the service of their peoples, and not vice versa." (Annan, 1999)

\section{The Responsibility to Protect}

In order to avoid any doubts and confusion, we must first and foremost try to understand and operationalise what we mean by the concept of Responsibility to Protect as stipulated by the International Commission on 
Intervention and State Sovereignty (ICISS). The concept implies that all "sovereign states have a responsibility to protect their own citizens from avoidable catastrophe - from mass murder and rape, from starvation - but that when they are unwilling or unable to do so, that responsibility must be borne by the broader community of states." (ICISS, 2001, p. VIII)

Despite the fact that there may be well-built humanitarian and moral justifications for a state's or group of states' intervention in the internal affairs of another state, there are always allegations that such interventions usually generate added bloodshed than they usually avert. Serious questions also remain on the conduct of such intervention operations. It is in view of this that during the latter part of 1999, Kofi Annan, the then UN secretary-general asserted that the UN and the world as a whole needed to adopt a better system, particularly for intervention - which "must be based on legitimate and universal principles" with "new actors, new responsibilities, and new possibilities for peace and progress" if the UN wanted to "enjoy the sustained support of the world's peoples." (Annan, 1999)

In response to the former UN Secretary-General Kofi Annan's call for the world to construct a new international accord which is capable of responding effectively and efficiently to the immense violations of international humanitarian and human right laws, Jean Chrétien - the Prime Minister of Canada at the time announced at the UN Millennium Assembly in September 2000 Canada's willingness to spearhead the establishment of an independent ICISS. This ICISS' responsibility would be the promotion of "a comprehensive debate on the issues, and to foster global political consensus on how to move from polemics, and often paralysis, towards action within the international system, particularly through the United Nations." (International Commission on Intervention and State Sovereignty (ICISS), 2001, p. 81) The international community was very hopeful that the outcome of the ICISS' work would introduce relatively fresh and efficient modes of merging the apparently "irreconcilable notions of intervention and state sovereignty" (ibid).

In accordance with its mandate, the ICISS' report attempts to address "the question of when, if ever, it is appropriate for states to take coercive - and in particular military - action, against another state for the purpose of protecting people at risk in that other state". Thus, addressing the issue of the "right of humanitarian intervention" was at the heart of the Commission's work (ICISS, 2001, p. VII). Though the Commission's report was basically completed before the 9/11 terror attacks, the ICISS' final report was nevertheless greatly influenced by the gruesome terrorist attacks on the US as that same month was scheduled for finalizing and making final adjustments to the final text of the report (ICISS, 2001).

The ICISS' mandate consequently required that, it through worldwide consultations, find suitable recommendations that could address questions that pertained to the moral and legal, as well as the political and operational dimensions of humanitarian interventions vis a vis state sovereignty and complaints of violations in that regard. It has been said that the times in which the UN and the world at large stand aside when gross and systematic violations of human rights take place are over and that the precedents of Rwanda and Kosovo are not satisfactory models for the new millennium. Thus, the ICISS had to find and recommend new ways of doing things as far as state intervention is concerned. (Annan, 1999)

Eventually, two basic principles underpin the concept of state responsibility. Firstly, according to the ICISS, "state sovereignty implies responsibility, and the primary responsibility for the protection of its people lies with the state itself." Secondly, it is postulated that in a situation where people suffer "serious harm, as a result of internal war, insurgency, repression or state failure, and the state in question is unwilling or unable to halt or avert it, the principle of non-intervention yields to the international responsibility to protect." (ICISS, 2001, p. IX) Nevertheless, one limitation on the ICISS' report was that it was intended to provide specific direction for "states faced with human protection claims in other states; it has not been framed to guide the policy of states when faced with attack on their own nationals, or the nationals of other states residing within their borders." (ICISS, 2001, p. VIII) This situation left unanswered several equally important questions pertaining to gross violations of human rights by states in the $21^{\text {st }}$ century.

Responsibility to protect as a concept accordingly implies three interrelated and interlocking emphatic tasks namely the responsibilities to prevent, react, and rebuild. Whereas the first two seek to address and mitigate the causes and continuance of conflicts and other human-induced predicaments that put people in danger, the third seeks to provide "full assistance with recovery, reconstruction and reconciliation" that are aimed at "addressing the causes of the harm" which may result from a military intervention operation carried out to "halt or avert" the conflict (ICISS, 2001, p. XI).

\section{The Responsibility to Protect, the International System and Implications for State Sovereignty}

Interestingly, one of the key principles that the ICISS' report outlines is the idea that postulates that: 
The Permanent Five members of the Security Council should agree not to apply their veto power, in matters where their vital state interests are not involved, to obstruct the passage of resolutions authorizing military intervention for human protection purposes for which there is otherwise majority support. (ICISS, 2001, p. XIII)

It is the view of the author that this particular idea is erroneous and only seeks to promote the interest of the five permanent members of the UNSC. As can be clearly read from the above sentence, the ICISS' report gives an indication that "the permanent five" can always have their way and make void any attempted resolution as far as such resolutions may affect their so-called "vital state interests." This situation only goes to strengthen the already lope-sided structure that the current international system has been perpetuating (Kwarteng \& Botchway, 2018). Here is a document purportedly meant to be addressing human needs, human rights, and humanitarian rights, yet clearly putting the interest of some particular presumably most powerful and important states above the lives and wellbeing of other people in other parts of the world. The position should rather have been to categorically and emphatically condemn the use of the so-called vital interests of those five countries as a pretext for preventing the promotion of humanitarian needs and not otherwise. Issues of humanitarian concerns should be treated logically and dispassionately. There should be no room for the so-called vital interests of any state whatsoever. If ever the need arose for the use of the so-called veto power, it should rather be in the form of applying a reverse consensus as argued by Botchway and Kwarteng (2018) and Kwarteng and Botchway (2018). This is the only true way to ensure accountability and the much touted sovereign equality of states that supposedly forms the basis for all foreign relations in the modern international system.

The situation is further worsened by the ICISS' assertion that "the application" of "the precautionary principle would on purely utilitarian grounds be likely to preclude military action against any one of the five permanent members of the Security Council even if all the other conditions for intervention described" were duly met. That is to say under no circumstances whatsoever at any point in time shall an intervention be carried out against any of the five permanent members of the UNSC. The Commission argues that:

It is difficult to imagine a major conflict being avoided, or success in the original objective being achieved, if such action were mounted against any of them. The same is true of other major powers who are not permanent members of Security Council. This raises again the question of double standards but the Commission's position here, as elsewhere, is simply this: the reality that interventions may not be able to be mounted in every case where there is justification for doing so, is no reason for them not to be mounted in any case." (ICISS, 2001, p. 37)

In other words, some countries are subject to and liable for interventions of any form while others are immune against same because they are 'more important' and powerful than others - an interesting phenomenon for an international system that claims to be operating on the basis of the sovereign equality of states and mutual respect for all sovereign states. All this is in light of the claims that the ICISS' report primarily focuses on intervention that is perceived as the "action taken against a state or its leaders, without its or their consent, for purposes which are claimed to be humanitarian or protective" coupled with the assertion that the genuine objective of any military intervention should be the "protection of a population, not defeat of a state." (ICISS, 2001, p. XIII, 8)

It has consequently been opined that the concept of responsibility to protect and its younger sibling - the duty to prevent "point to a new formulation of sovereignty as responsibility that in effect renders sovereignty conditional". These conceptions, as argued by Amitai Etzioni, "opens the door to treating nations not as free agents, but as members of an international community who are expected to adhere to that community's evolving norms regarding what is considered legitimate." (Etzioni, 2006, p. 72)

These new ideas of sovereignty as indicated by Etzioni (2006) further "opens a gaping hole in the foundation of democratic theory" in that the people may no longer be able to freely elect their representatives, and even when they do, the "new sovereignty precept" shifts critical decision and policymaking powers away from domestic governments to an "international forum" including the UN, WTO, IMF, World Bank, EU, AU, etc. This in effect implies that the citizens are in the best scenarios only offered a "limited representation" since a global agency "could rule that their government was acting irresponsibly without having to give the affected citizens the opportunity to affect the forum's judgments and positions." Consequently, it is asserted that "sovereignty as responsibility" only leads to the creation of a "democratic deficit that cannot be ignored in the quest for a new international order." (Etzioni, 2006, p. 72)

Accordingly, under what has become known as the new sovereignty mantra, sovereignty has become "an internationally shared responsibility" even as state sovereignty becomes "a privilege dependent on" the 
fulfillment of international obligations and global responsibilities (Etzioni, 2006, p. 74). State sovereignty under this circumstance can best be described as conditioned sovereignty - as the degree or extent of sovereignty is a function of the state's obedience and compliance with rules and institutions of a higher order- the so-called international community. The situation has also been described as the layered concept of sovereignty since the sovereignty of a state is "split between nations and supranational bodies" in the international system. (Etzioni, 2006, p. 83)

The nature of the international system has consequently led to the loss of the state's sovereignty. According to Jean Cohen, this has become possible because "key political and legal decisions are being made beyond the purview of national legislatures" (Cohen, 2004, p. 1). Thus, though the international system has witnessed several impressive developments, especially in the past two decades (both in terms of global governance and in the field of international law and cooperation), it is quite "premature and dangerous" for scholars to assert that these developments have ushered in a system of "cosmopolitan political constitution that should be or is in the process of replacing the international society of sovereign states and international law." (Cohen, 2004, p. 10) The point is that, the modern state is not that easily replaceable, especially because without states, there will be nothing like international community or system to even talk of institutions. It is therefore been opined that international practices that supports the classification of some states as "rogue" (criminal) and consequently justifies armed interventions as the "enforcement" of global right" only serves to authorize "the violator of international law to appear as the upholder of global constitutional legal norms." (Cohen, 2004, pp. 10-11)

Thus, not surprisingly, the US has over the years (and in recent times some of its western allies, particularly Britain and France) appeared to be "trying to position itself as the only power able to secure world peace and justice, police and punish violators, guarantee human rights, and protect democracy and "civilization" in the name of global right", engaging in so-called " "just wars'... and combating terrorism everywhere." It however usually seeks to achieve these goals "without subjecting itself to international law or participating in international institutions or in the international community." This attitude which has been aptly described as the attempt to build an "empire" only tends to reveal how modern practices have undermined and seeks to further undermine the very foundations of international law and global relations. (Cohen, 2004, p. 18)

\section{Conclusions}

In the contemporary world, members of the international community usually have the high expectations of states fashioning their domestic practices and laws along the lines of conventional international values, particularly on matters that bothers on humanitarian and global concerns. Failure to do so consequently implies that other responsible states have the "responsibility to interfere in the offending state's internal affairs." This forms the basis for humanitarian intervention - a practice which according to Etzioni "turns what was once a taboo of international relations into a moral imperative." (Etzioni, 2006, p. 73)

Studies have over the years shown that when societies tend to represent "culture politically", the end result is usually the creation of "special rights and privileges" which eventually leads to the concession of "formal equality" with it attendant challenges. (Aravamudan, 2006, p. 428) Similarly, over the ages, it has been a common practice for states to attempt to alter the configuration of the international system by waging wars with the hope often been to make the system "more amenable to their views." (Reynolds, 2018, p. 43) This consequently leads to a situation where one or more groups of states are given a privilege status in the international system while others are 'looked down upon'. The result is the disaffection among the members of the disaffected community who perceive that their sovereignties are been trampled upon, and their wellbeing ignored. For such countries, the question has always been that of unequal and unfair treatment which eventually leads to some nonstate actors (and sometimes state actors) within their borders to resist the international system and the laws they seek to promote. This is at the heart of most of the challenges confronting the world in the $21^{\text {st }}$ century (Botchway \& Kwarteng, 2018). The point is that States in the international system have always been pragmatic: they choose to "balance or expand based on relative advantage" and may equally resist when disaffected. (Reynolds, 2018, p. 45)

Given the recent developments in the international system, the idea that sovereignty must either be possessed in full or not at all, becomes quite simplistic in the contemporary world. Thus, sovereignty, if it even existed, and resembles what the Westphalian conceptions thought it to be, has actually become a shared responsibility: at least on paper. No single state or entity has absolute, inalienable, indivisible, and final legal authority over its inhabitants to the extent that it can do what it wants with them, and when it pleases to do what, especially when humanitarian issues are at stake. Even within a single state-be it federal or unitary one - sovereignty is usually distributed for the purpose of checks and balances (Thomas, 2013). 
In order to ensure justice, equality, equity, and orderliness in the international system, there is the need to divorce the well-touted concept of humanitarian intervention from what can be rightly or wrongly presumed to be humanitarian pretenses. Thus, any form of intervention undertaken in the name of humanitarianism should be legally justifiable and consistently coherent with enough evidence to substantiate any need for military action; and such actions should be human - centered - devoid of the whims and caprices of so-called superpowers and major powers and their parochial interests of whatever nature.

There is the general argument that though inaction on the part of the UN can result in terrifying consequences (as in the Rwandan genocide), so can the consequences of an intervention "without international consensus and clear legal authority" be disastrous as exemplified by NATO's military intervention in Kosovo. (Annan, 1999) Since the operations of the UN can only be effected in "a world of sovereign states", it has been argued that "its operations must be based in political realism" even though "the organization is also the repository of international idealism, and that sense is fundamental to its identity." Consequently, international law and practice requires that at any point in time "only the UN can authorize military action on behalf of the entire international community, instead of a select few." (ICISS, 2001, p. 52) However, in order to avoid unnecessary confrontations and contentions, there is the need to fine-tune some of the provisions on existing rules on state intervention and ensure that such rules are devoid of biasness towards less-privileged states. Moreover, coalitions or states are said to have acted "irresponsibly" when an intervention is carried out "without the will to restore peace and stability, and to sustain a post-intervention operation for as long as necessary to do so." (ICISS, 2001, p. 64)

It has therefore been argued elsewhere that "support for internal democratization", especially in situations where the so-called coalition of the willing states, or an individual state lacks the ability or willingness to restore peace and stability "must not be taken as a green light for violent interventions by powerful outsiders purporting to impose democracy" and "liberating the locals against their will and thus forcing them to be free." (Cohen, 2004, p. 21) The point is that "there is no customary rule that construes military intervention as the way to "enforce" human rights law." (Cohen, 2004, p. 22)

When the concept of sovereignty is also perceived as a "responsibility" - one that has actually "become the minimum content of good international citizenship" (ICISS, 2001, p. 8), it implies there is the corresponding duty to protect and to prevent. Consequently, proponents from different divides of the political spectrum (both progressives and neoconservatives respectively) are willing to sustain the claim that states "have a duty to intervene in failing or authoritarian states on humanitarian grounds" and that "intervention in such states is necessary to preserve national and international security" (Etzioni, 2006, p. 76).

In addition, there is the need to emphasise that any form of military intervention must be justifiable only when the action is necessitated by humanitarian crisis, and that it is "taken as a last resort" with the application of "only the minimum force necessary to complete the mission, and have reasonable prospects of success" and that no state whatsoever is immune from such an intervention when these guidelines are followed and the situation so permits (Etzioni, 2006, p. 80).

Though the use of force or military intervention may be regarded as a "part of the play of politics", it is indeed right to identify it as "a secondary part; a calculated means to achieve a given set of political ends" since most intervening states usually have their own agenda aside the touts of humanitarianism (Reus-Smit, 2004, p. 28).

In a nutshell, though the principles of self-legislation and non-discrimination demands that "those subject to the law should be its author" and that there is the need for "reciprocal commitments and equal application" of the laws respectively, evidence exist to show that the current international system deviates from these principles (at least in terms of state intervention and the responsibility to protect). (Reus-Smit, 2004, p. 39) It may therefore not be entirely wrong to agree with the assertion that the international system's and for that matter international law's proscription of the use of force "appears to emerge as a prohibition that exists in name only...." This stems from the fact that states, particularly the so-called powerful and major ones, would always have so-called justifications for their action and that some legal arguments can always "be rallied to their cause no matter what the circumstance." (Kritsiotis, 2004, pp. 48-49)

\section{Recommendations}

Both international laws and institutions can be strengthened and developed in a manner that would ensure the protection of human rights and the sovereignty of states while at the same time enhancing popular sovereignty, and the effective regulation of nonstate transnational groups that will promote rule of law at the global level. For this to be possible there is the need to disassociate "the tight link between autonomy and exclusivity" while effectively pursuing the gradual rejection of claims to absolute and "decisionistic concept of sovereignty in favor of the relational model." (Cohen, 2004, p. 19) 
Evidence abounds to attest that globalization usually creates situations that time and again demands certain actions "that no single nation-state can satisfactorily carry out." This scenario consequently calls for "some type of institutional "coordination" mechanism" that in effect causes "a powerful tension" between notions of time-honoured tenets of sovereignty and modern notions of internationalism - thus a tension between sovereignty and interference. (Jackson, 2003, p. 784) Diplomatically pursuing this institutional coordination will eventually help reduce the frequent frictions of intervention and state sovereignty.

In attempting to respond to the many extensive challenges and criticisms of the concept of sovereignty, Jackson has suggested that there is the need to "replace" sovereignty "with the phrase "sovereignty-modern"'- an approach which he perceives to be "more pragmatic and more empirically based." (Jackson, 2003, pp. 785, 801) $\mathrm{He}$ is of the view that pausing and having serious reflections on the subject of discarding the concept of sovereignty reveals some great ramifications that have been usually overlooked. He argues that given that "sovereignty is a concept fundamental to the logical foundations of traditional international law, discarding it risks undermining international law and certain other principles of the international relations system. Doing so could challenge the legitimacy and moral force of international law...." (Jackson, 2003, p. 801) This is a view that this paper supports, except that the paper does not see the need for the modification of the term since the proposed change from sovereignty to sovereignty - modern does not really make any changes to the true meaning and application of the concept.

History has shown that politics and law have always been two sides of the same coin. Consequently, the two cannot be mutually exclusive of each other - especially at the international level - and may at times be deemed as uneasy bedfellows. This notwithstanding, much efforts should be made to establish a clear distinction between the two. There is the need to draw the boundaries between how far politics can go into international law and vice versa. Thus, in the interaction of states, especially on matters of sovereignty, sovereign-equality, and questions of intervention, all states should be treated equally with dignity and respect irrespective of their military or economic might. The 'politics as usual' which seems to have engulfed the international system should not be given a room to operate in matters of state intervention - this should be made clear in all existing and future treaties, resolutions, and officially commissioned reports - if indeed the UN seeks to promote world peace and security. Rules on state intervention must be equally applicable to all states (including the P5).

\section{Acknowledgements}

The author is grateful to Benedicta Brobbey and Linda Peasah Owusu for their insightful comments and proofreading of the first draft of the manuscript.

\section{References}

Annan, K. (1999, September 16). Two Concepts of Sovereignty. Retrieved from https://www.economist.com/international/1999/09/16/two-concepts-of-sovereignty

Aravamudan, S. (2006). Sovereignty: Between Embodiment and Detranscendentalization. Texas International Law Journal, 427-446.

Bartelson, J. (2006). The Concept of Sovereignty Revisited. The European Journal of International Law, 17(2), 463-474. https://doi.org/10.1093/ejil/chl006

Bodin, J. (1576). Six Books of the Commonwealth (M. J. Tooley, Trans.) Oxford: Basil Blackwell.

Botchway, T. P., \& Kwarteng, A. H. (2018). Developing International Law in Challenging Times. Journal of Politics and Law, 11(3), 53-63. https://doi.org/10.5539/jpl.v11n3p53

Cohen, J. L. (2004). Whose Sovereignty? Empire Versus International Law. Ethics \& International Affairs, 18(3), 1-24. https://doi.org/10.1111/j.1747-7093.2004.tb00474.x

Dahl, R. A. (1957). The Concept of Power. Behavioral Science, 201-215. https://doi.org/10.1002/bs.3830020303

Etzioni, A. (2006). Sovereignty as Responsibility. Foreign Policy Research Institute, 71-85. https://doi.org/10.1016/j.orbis.2005.10.006

Family Watch International (FWI). (2013). Threats to National Sovereignty: UN Entities Overstepping Their Mandates. Gilbert, AZ: Family Watch International.

Hobbes, T. (1651). Leviathan or the Matter, Forme, \& Power of a Common-wealth Ecclesiasticall and Civill. London: Andrew Crooke. 
International Commission on Intervention and State Sovereignty (ICISS). (2001). The Responsibility to Protect: Report of the International Commission on Intervention and State Sovereignty. Ottawa: International Development Research Centre.

Jackson, J. H. (2003). Sovereignty - Modern: A New Approach to an Outdated Concept. The American Journal of International Law, 782-802. Retrieved from http://scholarship.law.georgetown.edu/facpub/110

Kritsiotis, D. (2004). When States Use Armed Force. In C. Reus-Smit (Eds.), The Politics of International Law (pp. 45-79). Cambridge: Cambridge University Press. https://doi.org/10.1017/CBO9780511491641.004

Kwarteng, A. H., \& Botchway, T. P. (2018). The North and South Divide in the Practice and Application of International Law: A Humanitarian and Human Right Law Perspective. Journal of Politics and Law, 11(1), 79-87. https://doi.org/10.5539/jpl.v11n1p79

Lansford, T. (2011). Sovereignty. In G. T.-I.-C. Kurian, G. T. Kurian, J. E. Alt, S. Chambers, G. Garrett, M. Levi, \& P. D. McClain (Eds.), The Encyclopedia of Political Science (pp. 1580-1584). Washington, DC: CQ Press.

Merriam Jr., C. E. (2001). History of the Theory of Sovereignty since Rousseau. Kitchener, Ontario, Canada: Batoche Books.

Nagan, W. P., \& Haddad, A. M. (2012). Sovereignty in Theory and Practice. San Diego International Law Journal, 429-520.

Potter, D. W. (2004). State Responsibility, Sovereignty, and Failed States. University of Tasmania, School of Government. Adelaide: Australasian Political Studies Association Conference.

Raustiala, K. (2003). Rethinking the Sovereignty Debate in International Economic Law. Journal of International Economic Law, 6(4), 841-878. https://doi.org/10.1093/jiel/6.4.841

Reus-Smit, C. (2004). Introduction. In C. Reus-Smit, The Politics of International Law (pp. 1-13). Cambridge: Cambridge University Press. https://doi.org/10.1017/CBO9780511491641.002

Reus-Smit, C. (2004). The Politics of International Law. Cambridge: Cambridge University Press. https://doi.org/10.1017/CBO9780511491641

Reus-Smit, C. (2004). The Politics of International Law. In C. Reus-Smit, The Politics of International Law (pp. 14-44). Cambridge: Cambridge University Press. https://doi.org/10.1017/CBO9780511491641

Reynolds, P. W. (2018). Long Wars: Demonstrating the Corrosive Effects of Irregular Wars on Dominant States. Social Sciences, 7(1), 43-54.

Thomas, K. R. (2013). Federalism, State Sovereignty, and the Constitution: Basis and Limits of Congressional Power. Washington, DC: Congressional Research Service.

\section{Copyrights}

Copyright for this article is retained by the author(s), with first publication rights granted to the journal.

This is an open-access article distributed under the terms and conditions of the Creative Commons Attribution license (http://creativecommons.org/licenses/by/4.0/). 